\title{
Introduction of the Personal Decision Support IT System in the Hungarian Public Service
}

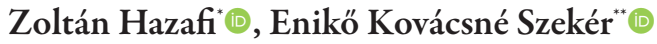 \\ * Associate Professor, University of Public Service, e-mail: hazafi.zoltan@uni-nke.hu \\ ** Lecturer, University of Public Service, e-mail: szeker.eniko@bm.gov.hu
}

\begin{abstract}
The most significant project of governmental HRM after 2010 has been the "Strategic Support for Succession Planning in a Competitive Civil Service". The name of the project underlines the focus placed on enhancing competitiveness and ensuring a sustainable, continuous supply of the workforce. Neither can be pursued without data-driven HR planning, so having an HRM decision support system in place is a critical element of the improvement. This study aims to address the issue of optimal headcount with regard to both domestic and foreign context, emphasise the importance of strategic HR planning and explore its results abroad. It suggests that by establishing the new HRM system, Hungary may become a country at the forefront of public service HRM and digitalisation.
\end{abstract}

Keywords: HR planning, public service, Human Resource Management, supply, digitalisation, statistics

\section{Competitiveness of the Public Service Sector}

The competitiveness of public service would typically be interpreted differently from the traditional definition of that term, as there is no competition market-wise. The main objectives of public service are serving the public interest, reducing social inequality, and granting access to public services at all levels of society. Thus, the competitiveness of public service lies in the ability of the state to drive a sustained development of social welfare through the achieved economic results. The definition of competitiveness received a broader interpretation at the meeting held by the European Council in 2000 in Lisbon, where it was viewed as a nation's ability to maintain the steady development of the living standards across their country, ensure a high employment rate and strong social cohesion. Eleven years later, the definition was extended at the Gothenburg meeting of the European Council to include the environmental aspect (Conseil Européen, 2011). 
At the same time, it is also the state's primary responsibility to maintain economic competitiveness (Imre, 2009). The various competitiveness reports evaluate several factors, such as stable governance, bureaucratic efficiency, the complexity of regulating corruption and tax burdens, the qualification level of the workforce, and infrastructure (Báthory, 2005). The HRM of the public sector impacts the capacity of governments directly and the country's economic competitiveness indirectly.

One of the crucial aspects of the quality of HRM is the headcount in public service. Wages take up the bulk of the operational expenditures. So, a headcount increase means a heavy budget burden, and the other way around: a headcount decrease enables the release of considerable budget resources to nurture economic growth.

Regardless of budget capacity, the ongoing growth and spread of bureaucracy are also political matters. Its uncontrollable expansion is undoubtedly an issue; the need to impose limits is frequently debated in political discussions. Anti-etatist movements attack the excessive centralisation of authority within public service through bureaucracy (Ruiz, 2017).

Let the headcount be up for discourse in any regard, the optimal number of employees and the rationale behind it are unavoidable issues.

\section{The optimal headcount}

The most critical aspect of human resource management is headcount optimisation. Nonetheless, an 'adequate' headcount is in fact impossible to establish (OECD, 2011). Comparing international data does not suffice as a basis for analysing the domestic headcount data.

Public service employment rates relative to the active population vary between 3.7 and 33.4 per cent in the OECD countries (OECD, 2019). The reason for the significant variance is that the scope of public service and the extent of outsourced services are different in each country. In countries where public tasks are outsourced, fewer people work in the public sector and vice versa. Thus, an international comparison is not suitable for defining indicators to measure the 'adequacy' of the headcount.

Domestic data cannot be utilised as a reference either; those are more suitable for identifying trends.

The period of the regime change in Hungary and the headcount data from 1989 are often referred to as the basis for measuring the magnitude of the changes that occurred later in the public sector. The headcount of the public service was around sixty-seventy thousand in the eighties, and rose to one hundred thousand between 1989 and 1994. This was due to the removal of the regulatory constraints affecting the public sector headcount management, as a result of which public service units became more independent and able to increase their headcount freely. However, there is a need for 'heavy' centralisation in headcount management to prevent anarchy (Lörincz, 1995).

It is worth looking into the changes of the headcount in public service on a longer timescale. In terms of the post-socialist era, data are available from the period between 
1994 and 2018. During that time, the headcount growth was 17 per cent in the public service sector.

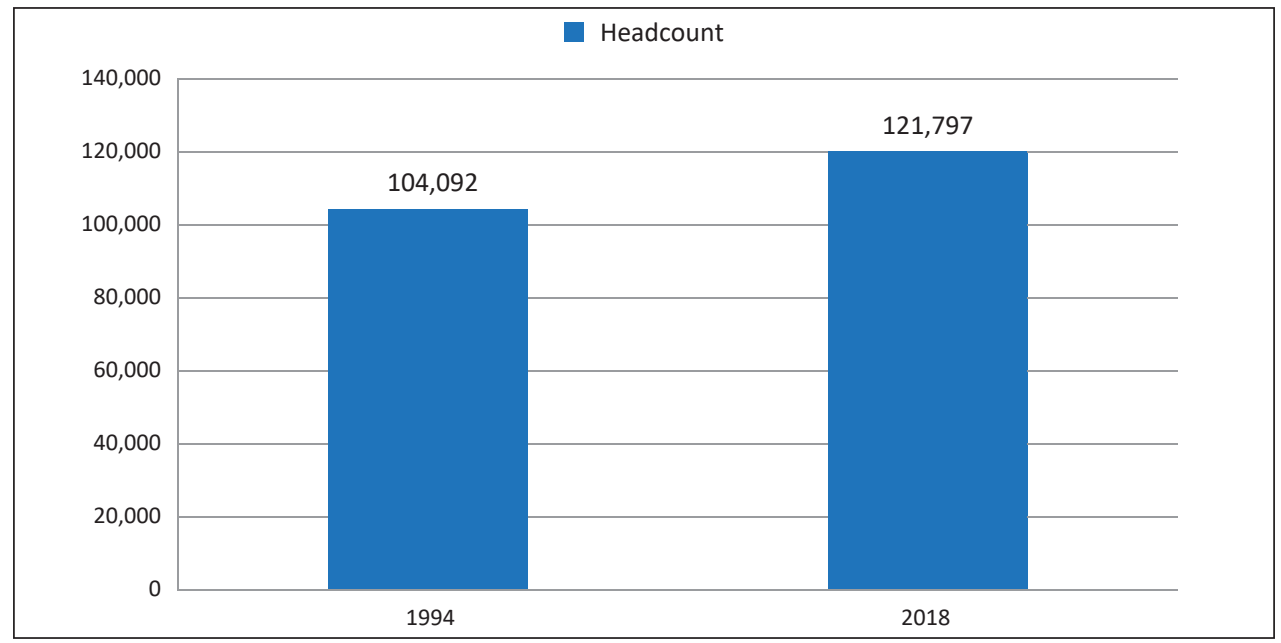

Figure 1.

Headcount of Public Service

Source: Compiled by the authors.

At the same time, it is apparent that minor decreases and repeated increases characterise the growth trend.

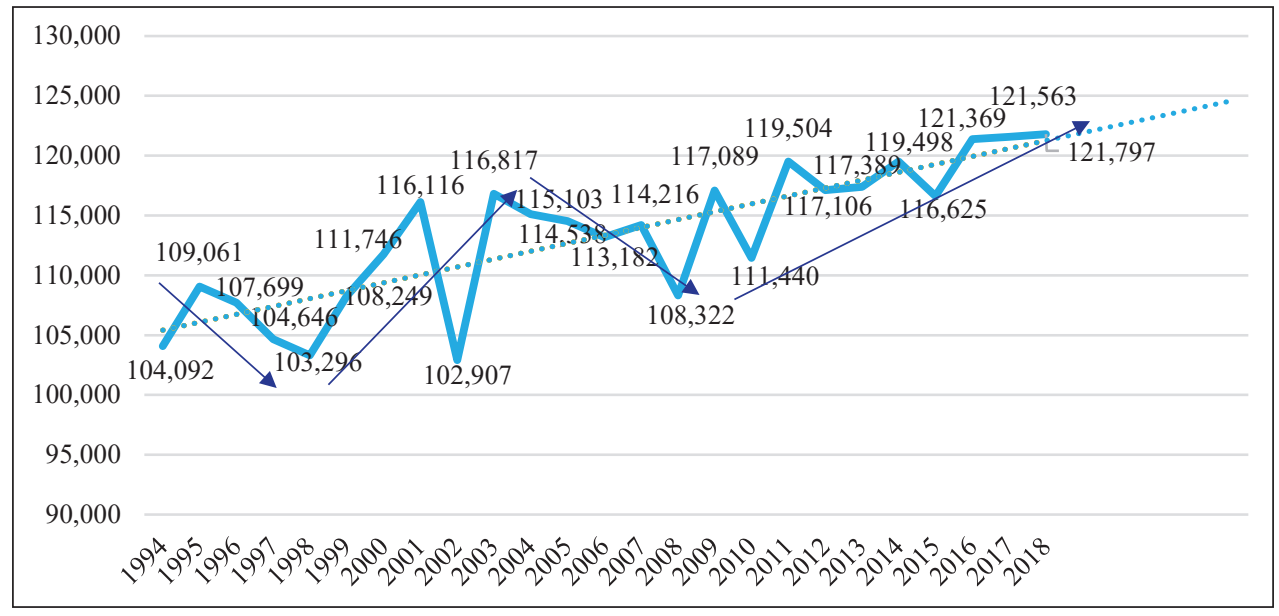

Figure 2.

Headcount of Public Service 1994-2018

Source: Compiled by the author. 
Generally speaking, the temporary decreases were due to central downsizing efforts made in the labour force. However, these top-down cutbacks did not yield steady headcount optimisation results.

The various acts of organisational restructuring proved similarly fruitless in terms of curbing the pace of headcount growth. In that regard, mostly organisational integration was applied in order to ensure cost efficiency. The number of public service units dropped from 720 to 216 between 1994 and 2018, mainly on a regional and local level.

The high ministry model, the merging of public service units fulfilling similar functions, and the integration of regional government units into the county (capital) government offices are examples of the organisational integration.

The overall headcount did not decrease due to the organisational integration, but the number of employees per unit increased significantly. While the average headcount per government unit was 71 in 1994, it rose to 376 by 2017 . Hence the average number of people employed per unit quintupled, meaning that the integration of government management resulted in significant employee concentration. ${ }^{1}$ Greater organisational size and headcount create favourable conditions for implementing an integrated, strategic human resource management.

The periodic downsizing attempts typically aimed at headcount optimisation, yet they served political and monetary interests rather than rational HRM objectives (Lörincz, 2010). Several historic examples support that: after the Treaty of Trianon, Hungary required public service on a much smaller scale than before World War I, and the headcount was decreased significantly twice during the 1920s. As a result of the B-listing in 1946, sixty thousand public servants were dismissed.

After the change of regime, several cutbacks occurred justified on financial, economic grounds; the best-known were the layoffs implemented as part of the austerity measures of the Bokros package in 1995.

A common feature of these workforce reductions was that instead of considering the actual needs based on workload, they used a pre-established percentage to lay off the same number of civil servants from all public service units, applying across-the-board cuts. Not to mention the fact that these headcount reductions were quickly reversed.

The fluctuation and the long-term growth of the headcount in public service show a domestic and an international tendency. As a reaction to the global financial and economic crisis in 2006-2007, some countries laid off a significant number of people employed in public service. For instance, in the United Kingdom, public service employment decreased by $3.1 \%$ between 2007 and 2017. The impact of this phenomenon completely diminished by 2017 nonetheless, and the level of public service employment increased in the vast majority of the countries - in Ireland to the most significant extent $(3.5 \%)$ - and it decreased in only a few cases, such as in Estonia (5\%) (OECD, 2019).

Own calculation based on data provided by BM KÖZIGTAD, BM KÖZSTAT, KSA. 


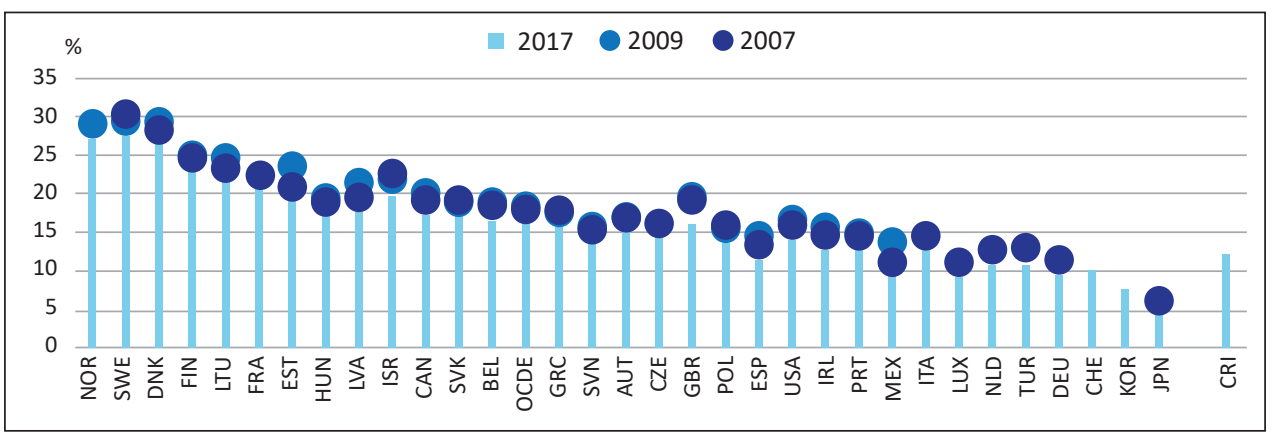

Figure 3.

Public service employment as a share of total employment in OECD countries

Source: OECD, 2019.

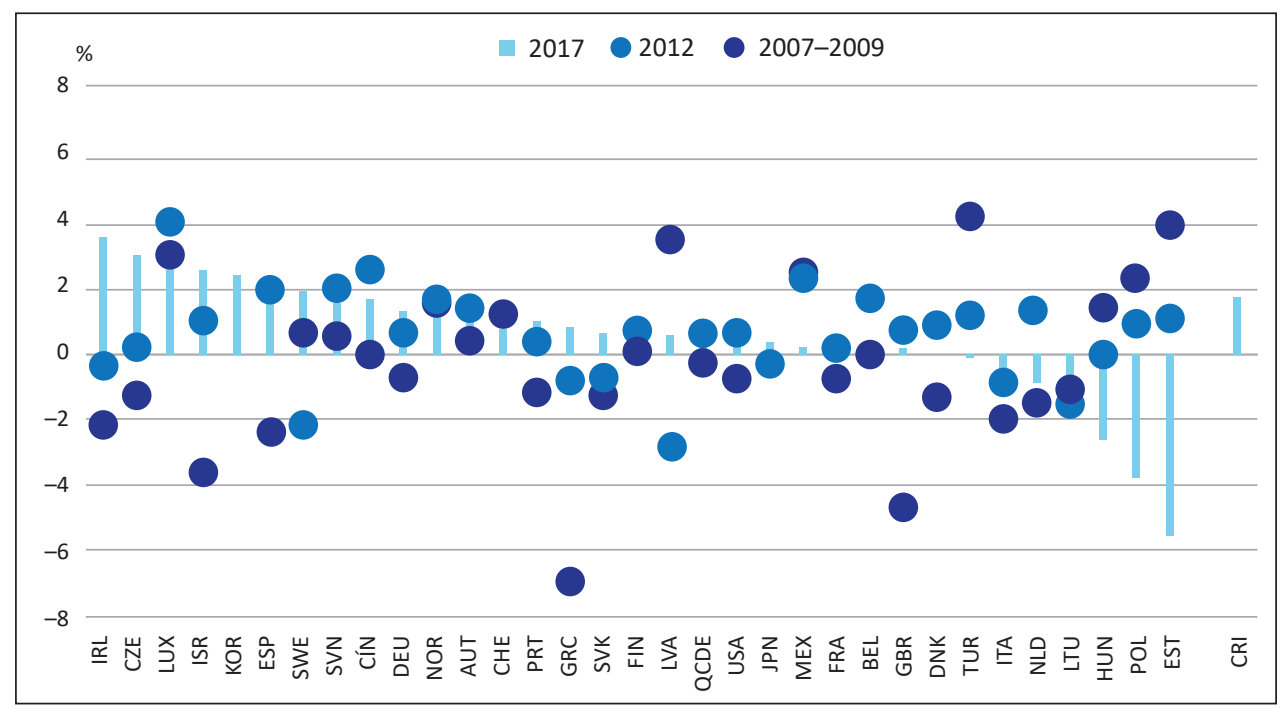

Figure 4.

Annual rate of change in public service employment

Source: OECD, 2019.

According to the latest statistical data, the OECD average of public service employment has stabilised at the rate of $17.9 \%$ in 2019 , as opposed to a rate of $17.71 \%$ in 2017 , although there still is significant variance between OECD countries. While the headcount decreased even further between 2007 and 2019 in the U.K., it increased in Spain, Estonia, Mexico, Slovenia and Norway. The overall employment rate also increased over the same period, although to a slightly lesser degree than in public service (OECD, 2021). 
All this proves that the 'optimal' number of public service personnel is determined by political motives rather than rational headcount management. It depends on the needs of the government and the intended role of the state in providing public services. Therefore, the purpose of this research should not be seeking an exact number considered optimal, but rather the means of shifting the headcount towards the optimal direction. Governments can influence the number of employees working in public service, as well as the otherwise determined processes by taking or not taking - certain reasonable personnel policy measures (Lörincz, 1995a). Strategic workforce planning is a part of those measures and an excellent tool to achieve the intended goals.

\section{Strategic workforce planning}

Strategic planning is a prerequisite to public service personnel policy. The precondition of strategic HRM is that the government have the data and information required to make personnel policy decisions. It also needs to obtain employee reports, use data spreadsheets for leadership and management decisions, apply data as the basis of workforce and training program planning and social dialogue, and inform the public regularly (OECD, 2017).

International experience has shown that the following areas can benefit from strategic workforce planning:

- developing and implementing staff policy objectives

- modelling the demographic changes (in terms of age and headcount composition) and their potential effects

- analysing the options of outsourcing (PPP, contracts, etc.)

- supporting the vertical and horizontal mobility of staff (temporary employments)

- investigating the possible resources to boost efficiency (e.g. advantages of e-public service, new technologies, working opportunities, etc.) (Melchor, 2013)

Strategic workforce planning is strongly linked to determining and evaluating competencies. In Canada, as part of the recovery from the financial and economic crisis, the public service reforms introduced were mainly centred on key competencies, such as agile leadership, innovative thinking, result orientation, value-based leadership and analytical thinking. The so- called VUCA (volatility, uncertainty, complexity, ambiguity) management method developed during the uncertain period following the Cold War (Johansen, 2012) has been revived.

In principle, they have been looking for leaders who:

- have a global aim and vision, motivate and inspire people for creativity (vision)

- actively listen to others, know well the strengths of their team members, and are confident about their need to perform (understanding)

- communicate clearly and able to collect relevant information (clarity)

- adapt quickly to the changing environment and needs (agility) 
In France, workforce planning is supported by a job roles directory (Le répertoire interministériel des métiers de l'État - RIME). It enlists reference job descriptions based on the required set of skills and competencies for each ministry position. Therefore, RIME is an integrated competency framework that standardises ministry job roles and job families. It has been continuously evolving since it is designed to track the changes in the operating environment of public service. The actualisation takes the top-down approach. The reference job descriptions are defined on a macro level without considering the differences between the job roles on a ministry level. It allows the ministries to integrate their jobs flexibly into the RIME system (Hazafi, 2020).

In the U.K., organisations have had to prepare knowledge management plans since the mid- nineties. The purpose of 'Departmental Improvement Plans' is to identify and evaluate the skills and competencies required within the organisation and advise on the directions the developments should take. Each public service unit prepares its own plan on an annual basis concerning its institutional strategy and the rest of its operational plans (Cabinet Office, 2013).

In Australia or the U.K., talent management strategies are also developed as part of the workforce planning. These strategies provide, inter alia, guiding principles on flexible working hours for the employees, opportunities for internal promotion and involvement in decision-making. Budget cuts force countries to reduce their public service headcount and wage costs. In an attempt to achieve that, more and more states decide to implement strategic planning of human capital into their operational agenda, which enables them to retain the necessary human capacity to perform tasks in the medium and long term, even in a restrictive operating environment. Workforce planning ensures that downsizing programs are not based solely on financial considerations but take other factors also into account, and that layoffs are linked to the restructuring of the task systems and HRM. It offers a chance to renew all HR processes and functions, such as recruitment, integration, competency management, remuneration, trainings, performance management, etc.

The development of workforce planning has complex conditions (Melchor, 2013). It requires the leaders to take a comprehensive view in their leadership approach and think strategically. Organisations need to have strategic objectives. When ensuring that the competency criteria for proper performance are met, cost-efficiency must also be taken into account. The government needs to respond quickly and flexibly to changes in the labour market, recognise future changes, and anticipate organisational development needs. These conditions are not given equally in each country. The coordination between human resource management and strategic policies is often insufficient, thus human resources planning fails to consider quantitative and qualitative human factors required to achieve policy objectives. Island-like solutions are applied which, instead of becoming a standardised and systematic approach, get stuck within the organisational framework. The institutional capacities and capabilities required for planning are limited. Rigid and centralised HRM practices are incapable of fulfilling the individual needs of the organisational units. There are no priorities, and organisational resistance is a common phenomenon (Melchor, 2013). 


\section{The implementation of an innovative Human Resources Management in the Hungarian Public Service}

In Hungary - as the first of the former socialist countries - the development of a human resources information database for centralised workforce planning started in the early 1990s as part of the career system development (KÖZIGTAD [Central Registry of Public Service Employees]). During the one and a half decades of its existence, it served the information needs of decision-makers related to the direction and improvement of the Hungarian public service. However, it could never fully fulfil its intended purpose.

The main reason for this was that the development of the Hungarian public service after the regime change did not fully follow the model of traditional career systems and did not centralise HRM. It allocated the respective competencies and exercise of employer rights to the leader of each organisation in a decentralised manner. This meant that the decentralised units - which were otherwise subordinate to the ministries - could independently appoint the members of their staff. The result was a highly fragmented system. In this organisational and legal environment, it did not make sense to maintain a central database whose task would have been to provide up-to-date data in line with the employers' needs, for the allocation and reallocation of employees, vacancy management and centralised recruitment. Instead, it was more of a rational decision to develop a system providing statistical data.

However, the use of statistical data has also been hampered due to the relatively high error rate in the data provided by the units and the low demand for empirical analysis.

For the reasons mentioned above, the KÖZIGTAD was discontinued in 2006 and replaced by a simplified system (e-KÖZIGTAD) with much narrower data content. It was later replaced by the Civil Service Statistical Data System, which collected and stored only aggregated statistical data, as opposed to individual data.

After 2010, the need to aid the decision-making in human resource management has been brought back into the focus of government personnel policy due to headcount planning, generational change, and the conceptual renewal of the legal framework for civil service careers. The fact that the government cannot anticipate staff transitions and the labour market demand of public service has become an increasingly pressing problem, which also hinders the government's ability to make medium- and long-term vacancy management plans and predict the potential impacts of ongoing changes on the organisational system and task structure. There is no coherent data set on public service personnel specifically designed to support strategic human resource decisions.

Currently, there is no integrated, efficient and sufficiently streamlined IT solution to meet government analysis and planning needs. Instead, the necessary information is usually obtained from other databases (KIRA [Central Payroll System], Central Statistics Office, Ministry of Finance) or ad hoc data collections, but their utility (e.g. comparability, trend mapping) is limited. 


\section{Former tools for HR reporting}

Despite having access to a wide range of IT innovations developed throughout the $21^{\text {st }}$ century, the decision-making process on the field of public service would still typically be based on data retrieval and manually processed information.

Although each public service organisation has a regular employee database that is used to support their HR decision-making, including their organisational structure and the data falling within the scope of personnel records prescribed by employment-related laws, it is utilised only on the level of the concerned unit. Until the introduction of the KSZDR, neither technology nor data protection rules allowed for such information to be channelled directly into sectoral or government decision-making.

Before public service personnel policy decisions were made, the central managerial units and the sectoral managing ministries provided ad hoc data to the organisations concerned. That data provision mechanism can be considered risky in several respects but has a questionable outcome in terms of its factual nature, to say the least.

These 'top-down' like data requests mainly submitted in Excel spreadsheets usually lead to aggregated results based on non-elementary data. The reliability of these data is often compromised because, in many cases, there are several ways to construe and define the obtained data, leading to different interpretations. A straightforward example of this would be when the decision-maker requests the reporting units for their headcount data, which might be meant as a statistical headcount, legal headcount, budgetary headcount, positions or status. If the request is not specified sufficiently, the data providers are likely to misinterpret it and provide incorrect information.

Furthermore, this type of HR data collection is time-consuming and can lead to data distortion or loss, typically in the course of data aggregation.

Nonetheless, to build a competitive public service sector, it is necessary to examine and assess or even forecast both on a governmental and organisational level where applicable - the impact of changes (reorganisation and restructuring) on the organisation system, task structure and workforce.

To that end, a decision-making support system is required to assist the government HRM to:

- collect, store and integrate data on the public service units, staff and job descriptions of the civil service (job register), and produce the required number and content of outputs (statistical function)

- monitor and compare the improvement of the human resources activities of the units and the main characteristics of their staff based on a varied set of criteria (e.g. sector, type of unit, hierarchical level) (monitoring function)

- integrate the various data, or their interconnected analyses and academic evaluations, as much as possible into governmental HR policy-making (analytical/ evaluation function)

- support the units in modelling changes in the organisation, tasks, job functions and staffing using the data stored in their system (institutional planning function) 
The question of an HRM information system for the public service has been raised during the planning of the Operational Programme for the Development of Public Administration and Public Services. It was developed as a part of the 'Strategic Support for Succession Planning in a Competitive Civil Service' project and introduced as the Government Decision Support System (KSZDR).

\section{The significance and characteristics of the Government Decision Support System (KSZDR)}

The KSZDR is an information system that supports the long-term HR management of the government and the institutions by collecting and analysing personnel data.

It seeks more efficient ways of utilising already existing HR data assets. As mentioned above, public service units still have organisational and HR records, most of which have been available electronically since 1998 .

At the same time, their utilisation remains local, so it is the task of the KSZDR to directly integrate this vast amount of available data into government decision-making and provide a decision support tool for its use. Currently, there are no tools to measure the efficiency of the decisions made and evaluate them; there is a lack of post-impact assessment that would help identify areas in need of further improvement.

The question is, what kind of substantial changes will the introduction of the new system bring? What tools and solutions will be applied by the KSZDR to allow for those changes? The following key concepts might be able to provide answers to these questions:

- Unit coverage: The KSZDR standardises the data system of public administration and law enforcement, which provides room for data comparison. The scope of data provision also covers state and local funded health care providers.

- Data scopes: The KSZDR consolidates the data structures that form the foundation of the database related to public administration, law enforcement and health care providers. It allows for running standardised statistical queries for standard and ad hoc purposes in terms of all legal statuses, covering all elements of the legal relationship. It also allows for the processing of specific data sets in the case of healthcare providers operated by the state and local governments.

- Functionality: Not only does it serve governmental HR decision-making with statistical data, but it also provides support to reporting units for the foundation, reorganisation and development of their organisation.

- Data source: Beside external data sources (MÁK-KIRA, KSH, TÉR, etc.), the KSZDR also uses its own data sources (the records of the units) to create the database. This not only allows for the comparison of public service, law enforcement and state-funded healthcare providers to one another but also to the public sector as a whole, providing a more comprehensive perspective.

- Regularity: The KSZDR ensures continuous data collection and updates certain data on a daily or weekly basis. 
- Method of data processing: After introducing the KSZDR, statistical processing and statements can be reproduced at any time. Aggregated reports can also be run without limits, in some cases even by automation (standard reports).

- Database maintenance: The introduction of the KSZDR provides standardised personnel recording and administration system in public service and law enforcement. The system will nonetheless fulfil profession-specific and individual employer needs and track legal changes without external developer updates.

\section{Structure and operation of the KSZDR}

The KSZDR is a type of information system, which supports the HR management of the government and public institutions by collecting and analysing workforce related data.

The development of the KSZDR is remarkable even at the international level. It digitalises the databases of personnel management records kept by each administrative and public service unit, as well as the data provided to the central database. It also integrates the IT applications developed separately earlier to support certain HR management activities, e.g. performance evaluation and recording training materials. Its reporting system allows for three types of analysis. On the one hand, it provides statistical data on personnel and HR activities for description and information. On the other hand, it enables the monitoring of the achievement of government objectives by applying certain indicators. Finally, it uses simulation models built from past data to forecast future trends and the long-term impact of government decisions, such as possible workforce fluctuations or the changes in terms of gender or age composition.

The KSZDR also allows the government to model the effects of organisational changes in the workforce using the so-called "corporate planning" function.

The system's main task is to collect and store the personal data of public service officials retrieved from the public service register kept by the public service units and, via an interface, from external databases (Performance appraisal: TÉR, KIRA).

KSZDR consists of two system elements, the Public Service Personnel Interface (KÖSZI) and the Decision-Making Support Centre (DTK).

\subsection{Public Service Personnel Interface: KÖSZI}

KÖSZI is a database which provides data connectivity between data sources suitable for communication, and offers data storage, query, maintenance, and authorisation functions.

It serves a dual purpose:

- it establishes a data connection between the regular personnel databases and the modules, ensuring the internal operation of the KSZDR, and helps to transfer complementary data from additional databases 
- provides a platform to the units authorised to use the system for entering, modifying and querying their data

KÖSZI stores the data in a transactional database. It consolidates the data recorded in different locations, organises them into a standard structure, and regularly completes data cleansing and refinement.

There is also an institution planning module available in KÖSZI, which allows the organisational hierarchy of public service units to plan their headcount, payroll and legal costs in a virtual environment.

\subsection{Decision Support Center: DTK}

It provides the data needed for statistical reporting. In the statistical module, the data of public service officials should be recorded anonymously, in line with the order specified in the relevant Government Decree.

The reporting system of the DTK consists of three types of analysis: reports, monitoring and analytical evaluation system.

\subsubsection{Reports}

Reports help to describe and understand the personnel and HR activities (in other words, the subsystems and HR processes) with the help of statistical data. To set personnel policy goals, we need to know the essential characteristics of the workforce, e.g. headcount, age, professional background, etc. The same applies to HR activities; we can only define development objectives and directions after gaining a clear picture of each of them. The statistical data used for this purpose describe the characteristics of the personnel on the one hand, and those of the HR activities on the other hand. The former includes demographic, status (legal status) and sociological data on human resources, as opposed to the latter which includes quantitative and qualitative data on HR functions (recruitment, career development, remuneration, appraisal, development, responsibility, exit).

Statistics not only allow us to gain a deeper insight into the personnel of public administration and law enforcement in terms of essential characteristics - such as headcount, age or educational background - and to explore its internal relations, but also enables us to specify the place (position) of this personnel in the public service in a broader sense (all who are employed by budgetary units, hereinafter: the public sector).

The demand for such positioning stems from the fact that the regulation of the Hungarian public service system is highly fragmented in terms of legal status as it comprises several 'public service legal relationships'. Another reason is that the organisational delimitation of the KSZDR is limited.

Positioning also involves demonstrating and analysing trends affecting certain legal statuses, e.g. the aging of workforce in administrative, law enforcement, judicial units 
and public service institutions. Comprehensive public sector analyses can help prepare government measures to coordinate a highly fragmented system, e.g. how different remuneration systems affect fluctuations in each legal relationship or mobility within the system.

The system distinguishes between two types of reports, standard reports and case reports. Standard reports are lists, tables, pivots and charts ${ }^{2}$ with fixed content and structure that are regularly pulled to meet periodic information needs. They can be accessed in two different manners. Some reports are drawn with an automated query in a customised manner to organisations, groups and users, with a targeted report distribution. These queries are not run by users; they are executed automatically once a month. The rest of the standard reports can be accessed by manually querying a user interface selected from an established report catalogue.

The access of each report requires authorisation; only certain users or groups can use, run, or edit them. The reports can be exported into standard file formats.

Users can create additional standard reports from the DTK data scopes. The system provides a visual platform for report planning with templates, aggregation functions (amount, average, minimum, maximum, etc.), relating jargon, calculated fields and queries. In addition to tabular display, the system also supports graphical display (e.g. column chart, pie chart) and aggregates data to each level of the organisational hierarchy (e.g. institution, central unit, sector).

DTK also enables running individual, ad hoc queries. An ad hoc query is a type of report which allows the user to pull multiple variations of different facts and indicators within the same report in a predefined scheme and dimensions to get specific information when it is needed. The user creates the content. ${ }^{3}$

\subsubsection{Monitoring}

Monitoring is a narrower intersection of reporting, which is different from other types of report as it is based on performance indicators and pulled annually. The evaluation of the indicators shows the stagnant or changing tendencies over the year.

The tracking of changes in the workforce and the development of $\mathrm{HR}$ activities, the objectives met, and the impact of the measures taken are assessed based on indicators and targets, e.g. the percentage of fresh graduates being hired or the percentage of fresh graduates resigned, etc.

It is also examined to what extent and how the actual results vary from the desired outcome. Statistical analyses are also included in the monitoring reports.

The indicators are predefined. Not all indicators can be derived from the data stored in the record of the units, so there is also an option to form them based on data retrieved from external sources or inputs gathered from questionnaires.

\footnotetext{
The tool used for drawing up standard reports is Pentabo Report Designer.

3 The tool used for drawing up ad hoc reports besides Pentabo Report Designer is Saiku Analytics.
} 
Some examples of indicators are:

- change of managerial headcount compared to the same time of the previous year

- number of team members per team leads

- number of vacancies

- the ratio of men and women

- employment rate of people under thirty

- exit rate

- annual labour turnover

- annual entry and exit turnover

- the share of income deciles

- change in the average monthly gross salary per person compared to the same time of the previous year

- labour cost per capita

- the share of the number of people employed by the budgetary units within the economically active population

The system consists of 616 indicators in total.

It is possible to display reports and critical indicators for complex and quick conclusions simultaneously in a management information interface. Data can be displayed in tabular, chart, or map format. Further reports are available with links, and export files can be downloaded for detailed display and further analysis of certain reports.

\subsubsection{Analytical evaluation system}

The analytical evaluation module helps answer the 'What If ?' question. When all the necessary conditions are in place to make an HR decision affecting public service either partially or entirely, it is essential to carry out various impact assessments, i.e. the decision needed to take the potential consequences into account. However, in order for the necessary information to be available to decision-makers within a short period of time and in reliable quality, it is essential to use analytical methods and evaluation with business intelligence tools capable of exploiting the DTK's data assets.

The flexible analytical evaluation system allows for the preparation of simulations of the potential future position of the workforce. Thus, based on the fluctuation trend of the previous 3-5 years, the system can model the expected fluctuations in the upcoming years. Fluctuation simulation can be displayed over several variables (e.g. age composition, education, etc.). Similarly to the fluctuation model, the system is also able to forecast the impact of salary changes on personnel (e.g. if a headcount increase is planned, the simulation models the expected increase in wage costs).

The results of the analytical evaluation can serve research needs that help to identify, analyse and assess HRM processes that cannot be managed in other functions.

DTK reports can be used to extend the selection of workforce indicators affecting the Good State indicators in the following areas: 
- fluctuation: the number of terminated employments reported by public service units, annually cumulated data broken down by county, public service level (central/regional) and/or organisation types, the legal relationship (public service official, government official, state official, etc.), reasons for terminating employment

- gender ratio: annually, the annual number of employees in public service by gender, broken down by team leads and team members

Age composition of public service workers (per year): these analytical needs are the same as previously discussed analyses, so there is no need to include them as a separate need.

The analyses offered by the KSZDR are also suitable as a basis for serving international statistical and analytical needs. Therefore, the KSZDR can also contribute to the fulfilment of the reporting duties of institutions ( $\mathrm{KSH}$ and other organisations) that currently provide data to international organisations concerning the field of public service personnel.

\section{Conclusion}

Headcount is a crucial factor in the competitiveness of the civil service. Ideally, we should be able to determine the optimal number of people employed, but conditions are not in place for that. Nonetheless, we can still shift the headcount in the optimal direction by strategic workforce planning and using an integrated information database. The KSZDR will be a tool for the government to reform workforce planning and human resource management processes. The ability to adapt quickly and dynamically to change makes any tool a valuable asset that provides decision-makers with a strong reference point. The author of these lines trusts and believes that the KSZDR becomes such a benchmark.

\section{References}

Báthory, Zs. (2005). Az IMD és a Weforum versenyképességi jelentéseinek struktúrája és módszertani háttere. Mủhelytanulmány (working paper). Budapest, Vállalatgazdaságtan Intézet.

Departmental Improvement Plans. GOV.UK. (2015). Online: www.gov.uk/government/collections/ departmental-improvement-plans

De Kerviler, I. (2011). La compétitivité: enjeu d'un nouveau modèle de développement. Journal officiel de la République française, 20-25. Online: www.lecese.fr/sites/default/files/pdf/Avis/2011/2011_11_ competitivite.pdf

Fogarasi, J. (1995). A közigazgatás személyi állománya (pp. 205-209). Unió.

Európai Tanács (2011). La compétitivité: enjeu d’un nouveau modèle de développement. www.lecese.fr/sites/ default/files/votes/professions-liberales_competitivite.pdf

Gajduschek, G. (2008). Közszolgálat - A magyar közigazgatás személyi állománya és személyzeti rendszere az empirikus adatok tükrében (közigazgatási olvasmányok). Magyar Közigazgatási Intézet. 
Gáspár, M., \& Szakács, G. (2018). Munkaköralapú humánerőforrás gazdálkodás intézményesítésének nemzetközi gyakorlata (országtanulmányok) (1st ed., pp. 413-438). Nemzeti Közszolgálati Egyetem.

Hazafi, Z. (2020). Munkakör-és kompetencia-alapú stratégiai humán erőforrás gazdálkodás a francia közszolgálatban. In Gáspár, M. \& Szakács, G. (Eds.), Munkaköralapú humánerőforrás gazdálkodás intézményesítésének nemzetközi gyakorlata (országtanulmányok) (pp. 413-438). Nemzeti Közszolgálati Egyetem.

Imre, M. (2009). Az állam és a közigazgatás gazdasági szerepe és feladatai. In Verebélyi, I., \& Imre, M. (Eds.), Jobb közigazgatás helyben járás és visszafejlödés helyett (pp. 28-36). Századvég Kiadó.

Johansen, R. (2012). Leaders Make the Future: Ten New Leadership Skills for an Uncertain World. 2nd ed. Berrett-Koehler Publishers.

Linder, V. (2010). Személyzet politika - Humán stratégia a közigazgatásban (PhD thesis).

Lőrincz, L. (1995). A közigazgatás létszámáról. In Fogarasi, J. (Ed.), A közigazgatás személyi állománya (pp. 205-209). Unió Lap-és Könyvkiadó Kereskedelmi Kft.

Lőrincz, L. (2010). A közigazgatás alapintézményei. HVG-ORAC.

Melchor, O. H. (2013). The Government Workforce of the Future: Innovation in Strategic Workforce Planning in OECD Countries. OECD Working Papers on Public Governance, pp. 22-26. Online: https://doi. org/10.1787/5k487727gwvb-en

Molnár L., \& Udvardi A. (2016). Versenyképességi évkönyv Magyarország helyzetének változása a régiós versenyben. GKI Gazdaságkutató Zrt. és Friedrich-Ebert-Stiftung.

OECD (2011). Public Servants as Partners for Growth: Toward a Stronger, Leaner and More Equitable Workforce. OECD Publishing. Online: https://doi.org/10.1787/9789264166707-en

OECD (2019). Panorama des administrations publiques 2019. Éditions OECD. Online: https://doi. org/10.1787/8be847c0-fr

OECD (2021). Panorama des administrations publiques 2021. Éditions OECD. Online: https://doi. org/10.1787/9556b25a-fr

Ruiz, É. (2017). Des économies très politiques. Cahiers d'histoire. Revue d'histoire critique, 134, 65-85. Online: https://doi.org/10.4000/chrhc.5753

Soliman, K. (2017). Vision 2020: Sustainable Economic development, Innovation Management, and Global Growth. Proceedings of the 30th International Business Information Management Association Conference (pp. 904-916). Madrid, IBIMA.

Verebélyi, I., Miklós, M., \& Gellén, J. (2009). Jobb közigazgatás helyben járás és visszafejlödés helyett (pp. 28-36). Századvég. 